\title{
EFFECTS OF THE USE OF INTERACTIVE TEXTBOOKS ON EDUCATION
}

\author{
Petr SIMBARTL*, Západočeská univerzita v Plzni, Česká republika
}

Přijato: 30. 4. 2016 / Akceptováno: 7. 10. 2016

Typ článku: Výzkumná studie

DOI: $10.5507 /$ jtie.2016.030

Abstract: Digital books are used more often nowadays. As these textbooks are able to better mediate some information, it may be assumed that children improve their study results. Based on the pedagogical experiment, the goal is to verify this idea. The pedagogical experiment was carried on two primary schools. The first of the schools joined with one experimental class (where an interactive textbook was used) and two control classes (where the usual paper textbooks were used). The positive effect was proved only partially. Having examined all samples from both of the schools (134 tests in total) and considering influencing factors, the main hypothesis has not been proven: "The group taught by means of interactive textbooks achieves better study results in testing the knowledge and thinking operations with the knowledge than the group taught by means of paper textbooks only."

Key words: interactive textbook, geography, primary school, multimedia

\section{VLIV POUŽÍVÁNÍ INTERAKTIVNÍCH UČEBNIC NA VÝUKU}

Abstrakt: Digitální knihy jsou dnes rozšiřenější. Protože mohou tyto učebnice lépe zprostředkovat informace, dalo by se predpokládat, že by děti mohly mit lepšsi studijní výsledky. Na základě našeho pedagogického experimentu jsme tuto myšlenku ověrili. Pedagogický experiment probihal celkem na dvou základnich školách. V první škole byla jedna tř́da experimentální (využivala se interaktivní učebnice) a dvě kontrolní (použivaly se pouze papírové učebnice). Pozitivní vliv byl prokázán pouze částečně. Po prozkoumáni všech vzorků testů z obou škol (celkem 134) a zohledněni ovlivňujicich faktorů jsme odmitli hlavni hypotézu: „Skupina vyučovaná za pomocí interaktivni učebnice dosáhne lepšich studijních výsledků z didaktických testů na znalosti a myšlenkové operace se znalostmi než skupina vyučovaná pouze pomocí papírových učebnic. "

Klíčová slova: interaktivní učebnice, zeměpis, základní škola, multimédia

*Autor pro korespondenci: eurogo@kmt.zcu.cz 


\section{1 Úvod}

Vývoj technologií mění i formát učebnic. Mnohá nakladatelství produkují souběžně s papírovými učebnicemi také digitální. Forma vytvoření může zůstávat jen u čistě digitální podoby (podobné PDF) nebo jsou k dispozici interaktivní učebnice obsahující mnoho multimédií reagujících na činnost žáka. Učitel je může dále rozšiřovat i o vlastní části. Protože mohou tyto prvky lépe zprostředkovat informace uváděné v učebnicích, dalo by se předpokládat, že by děti mohly mít větší zájem o probírané učivo, či se dokonce zlepšit ve studijních výsledcích. To jsou pouze predpoklady a skutečný vliv může být jiný. Cílem našeho pedagogického experimentu bylo ověření vlivu používání interaktivních učebnic na studijní výsledky žákủ. Využijeme k tomu vzorek ze dvou škol a za použití statistických metod přijmeme či odmítneme naši hlavní hypotézu: „H1: Skupina vyučovaná za pomocí interaktivní učebnice dosáhne lepšich studijnich výsledki̊ $z$ didaktických testũ na znalosti a myšlenkové operace se znalostmi než skupina vyučovaná pouze pomocí papírových učebnic. " (Simbartl, 2015). Míra využití digitálních učebnic také narůstá. V Německu využívají od roku 2012 společného portálu na distribuci digitálních učebnic a žákům to usnadňuje nákup. (VBM Service GmbH). Hromadný přechod na digitální učebnice se konal např. v Jižní Koreji (Pearson Plc.).

\section{Metody a podmínky pedagogického experimentu}

Přestože v mobilním počítačovém světě převládají aktuálně tablety, využili jsme interaktivní učebnici jako hlavní prostředek pouze na interaktivní tabuli. Nebylo by možné, aby si každý žák pouštěl při výuce video sám pro sebe. Rovněž finanční náklady na nákup kvalitních tabletů nejsou nízké.

Náš pedagogický experiment probíhal ve formě využití interaktivní učebnice na interaktivní tabuli. Žáci využivali pouze papírové učebnice. Na interaktivní tabuli mohli plnit cvičení a rovněž byla využita jako promítací plocha pro učebnici (text, přehrávání videí, zobrazování animací). Tato forma byla $\mathrm{v}$ experimentální skupině. V kontrolní skupině probíhala výuka standardním způsobem pouze za pomocí papírových učebnic.

\section{Průběh}

V průběhu pedagogického experimentu byly dodrženy tyto podmínky:

- Žáci z obou skupin byli vyučování stejným vyučujícím.

- Využívali stejné učebnice jen $v$ jiné formě.

- Rozsah učiva se shodoval. (Rozdíl byl pouze $\mathrm{v}$ netextové části, kde v experimentální trrídě viděli animace, videa a někdy i více obrázků. Interaktivní učebnice také nabízela např. lepší srovnání grafư.)

- Stejný počet výukových jednotek.

- Stejný posttest.

Ovlivňující faktory:

- Téma výuky (testu).

- Období, ve kterém se píše test (začátek školního roku, pololetí, atd.).

- Počáteční znalosti. 
Důvodem zachování papírových učebnic je fakt, že přestože jsou k dispozici tablety, nejsou zatím všude dostupné. V první fázi nasazení (prodeje) interaktivních učebnic se rovněž neočekával větší podíl tabletů.

V našem experimentu byla využívána učebnice Fraus zeměpis pro 6. ročník (Červený et al., 2009). Po testování vydalo nakladatelství již novou učebnici. Struktura učebnice a obsah je zachován, provedli jen některé úpravy a revize textů.

Plán experimentu:

- Způsob výběru škol a žáků: príležitostný výběr.

- Proškolení vyučujících a seznámení s konkrétní interaktivní učebnicí.

- Provedení experimentální výuky ZŠ Nýřany (tř̌i třídy): počet žáků 19, 20, 23.

- $\quad$ Posttest

- Vyhodnocení

- Provedení experimentální výuky ZŠ Starý Plzenec (dvě třídy): počet žáků $19,18$.

- $\quad$ Posttest

- Provedení experimentální výuky ZŠ Starý Plzenec (dvě tř̌́dy) - rotace faktorů

- $\quad$ Posttest

- Vyhodnocení

- Celkové vyhodnocení experimentální výuky

\section{Vyhodnocení}

Celkem bylo $\mathrm{k}$ dispozici 134 testů. Při jednom testování docházelo $\mathrm{k}$ rotaci faktorů, proto uvádíme počet testů než žáků, avšak nám to přineslo dobré výsledky. Velikosti tř́́d byly rovnocenné.

Testování učebnice (provedení experimentu) probíhalo po dobu 8 výukových jednotek $(8 \times 45$ minut) a poté následoval test. Do standardního průběhu školního roku nebylo zasahováno a známka získaná z testu, který byl použit pro výzkum, byla běžně započíána, tudíž měl žák snahu získat dobré hodnocení. Někteři žáci byli vyřazeni, protože napríklad nepsali jeden $\mathrm{z}$ testů nebo ho nepsali v řádném termínu. $\mathrm{V}$ opakovaném termínu byl test stejný a bylo by zde riziko ovlivnění výsledkủ.

Testování probíhalo na dvou základních školách, proto vyhodnocení proběhlo odděleně. Získané výsledky lze $\mathrm{v}$ závěru částečně porovnávat a určit platnost naší hlavní hypotézy.

Pro testování nebyly k dispozici standardizované testy. Abychom zachovali shodnost a obtížnost testu, byla stanovena některá kritéria (srovnatelnost typů učebních úloh a obtížnosti testových otázek). Vytvořené otázky měly být $\mathrm{v}$ prvních dvou kategoriích dle taxonomie učebních úloh podle D. Tollingerové, uvedené v Kalhous,Obst a kol.(2009, s. 331).

\section{První kategorie / druhá kategorie učebních úloh}

Nýřany 1. test: $7 / 6$

Starý Plzenec 1. test: 9/4

Starý Plzenec 2. test: 10/3 
Rozdíly jsou minimální (především u druhé školy - rotace faktorů), většina otázek měla směřovat do první kategorie. Dủležitějším parametrem je obtížnost.

Následně proběhlo testování a byla provedena analýza testových úloh, podle vzorců Chráska (1999, s. 46-47). Zjistili jsme hodnoty obtížnosti Q, kdy hodnota menší než 20 znamená velmi snadnou úlohu a hodnoty vyšší než 80 jsou obtížné úlohy. Optimální hodnota se pohybuje kolem 50 .

\section{Měli jsme tyto hodnoty: \\ Q Nýřany 1. test: 43 \\ Q Starý Plzenec 1. test: 46 \\ Q Starý Plzenec 2. test: 36 \\ (Simbartl, 2015)}

$\mathrm{Na} Z$ ZŠ Nýřany jsme porovnávali výsledky z testů, kde 6 . A byla experimentální skupina a 6. B, 6. C kontrolní skupina. Výsledky prošly Shapirov-Wilkovým testem normality. Zjistili jsme, že naše data jsou normálně rozdělena. Dále jsme provedli F-test na rozptyl, zjistili jsme, že se rozptyl vzorků (6. A, 6. B) od sebe neliší. Vzorky (6. A, 6. C) se od sebe statisticky lišily.

Před tím jsme si položili tyto dílčí nulové a alternativní hypotézy pro ZŠ Nýřany:

„H10-NI: Používání interaktivní učebnice ve výuce v experimentální skupině 6. A nebude mít pozitivní vliv na studijní výsledky zdidaktických testů na znalosti a myšlenkové operace se znalostmi oproti skupině 6. B vyučované pouze za pomocí papírových učebnic.

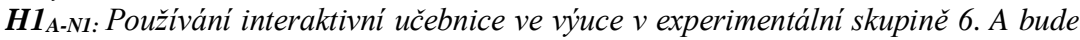
mít pozitivní vliv na studijní výsledky $z$ didaktických testů na znalosti a myšlenkové operace se znalostmi oproti skupině 6. B vyučované pouze za pomocí papírových učebnic.

H10-N2: Použivání interaktivní učebnice ve výuce v experimentální skupině 6. A nebude mít pozitivni vliv na studijní výsledky zdidaktických testů na znalosti a myšlenkové operace se znalostmi oproti skupině 6. C vyučované pouze za pomocí papirových učebnic.

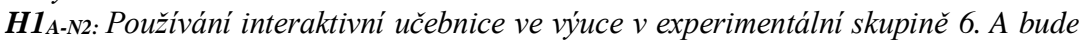
mít pozitivní vliv na studijní výsledky $z$ didaktických testů na znalosti a myšlenkové operace se znalostmi oproti skupině 6. C vyučované pouze za pomocí papírových učebnic" (Simbartl, 2015).

$\mathrm{Na}$ základě rozptylů jsme potom provedli pro skupiny dvouvýběrový T-test $s$ rovností a nerovností rozptylů.

Dvouvýběrový $\mathrm{t}$-test $\mathrm{s}$ rovností rozptylů na střední hodnotu skupin 6 . A a 6 . B na hladině významnosti $\alpha=0,05$ nám zjistil hodnotu $p=0,0000159$, protože je hodnota $\mathrm{p}<0,05$ byla zamítnuta $\mathrm{H} 1_{0-\mathrm{N} 1}$ pro skupinu 6 . A a 6 . B a přijata $\mathrm{H} 1_{\mathrm{A}-\mathrm{N} 1}$. Využití interaktivních učebnic mělo pozitivní vliv na výsledky žákủ v experimentální skupině.

Dvouvýběrový t-test $\mathrm{s}$ nerovností rozptylů na střední hodnotu skupin 6 . A a 6 . C na hladině významnosti $\alpha=0,05$ zjistil hodnotu $\mathrm{p}=0,0022986$, protože je hodnota $\mathrm{p}<0,05$ byla zamítnuta $\mathrm{H} 1_{0-\mathrm{N} 2}$ pro skupinu 6 . A a 6 . C a přijata H1 A-N2. Využití interaktivních učebnic mělo pozitivní vliv na výsledky žákủ v experimentální skupině. 
U obou tř́id, na základě získaných výsledků testů, byl prokázán signifikantní vliv na znalosti a myšlenkové operace se znalostmi oproti skupině vyučované pouze za pomocí papírových učebnic.

Celkové vyhodnocení experimentu se provedlo s výsledky z druhé školy.

V ZŠ Starý Plzenec jsme srovnávali výsledky tř́íd opět při využívání interaktivních učebnic nebo pouze papírových, ale srovnávali jsme výsledky vždy od každé třídy samostatně (rotace faktorů). Ovlivňující faktor bylo téma.

Provedli jsme Shapirov-Wilkův test normality. Pro oba testy 6. A byla získaná data normálně rozdělena. Pro oba testy tř́dy 6 . B byla normalita dat mírně narušena. Odchylka nebyla však velká, aby poškodila platnost závěrů. Dále jsme použili dvouvýběrový F-test na rozptyl. Data pro skupiny testů 6 . A i skupiny testů 6 . B od sebe statisticky významně nelišila.

Ve Starém Plzenci jsme si zvolili tyto dvě dílčí nulové a alternativní hypotézy:

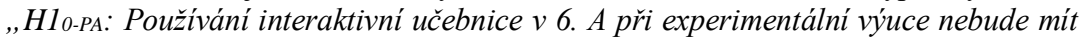
pozitivní vliv na studijni výsledky z didaktických testũ na znalosti a myšlenkové operace se znalostmi oproti výuce jen za pomoci papirových učebnic.

$H 1_{A-P A}::$ Použivání interaktivní učebnice $v 6$. A při experimentální výuce bude mít pozitivní vliv na studijni výsledky z didaktických testů na znalosti a myšlenkové operace se znalostmi oproti výuce jen za pomocí papírových učebnic.

H10-PB: Použivání interaktivní učebnice v 6. B při experimentální výuce nebude mít pozitivni vliv na studijni výsledky z didaktických testů na znalosti a myšlenkové operace se znalostmi oproti výuce jen za pomocí papirových učebnic. "

$H 1_{A-P B}$ : Použivání interaktivní učebnice $v 6$. B při experimentální výuce bude mít pozitivni vliv na studijni výsledky z didaktických testů na znalosti a myšlenkové operace se znalostmi oproti výuce jen za pomocí papirových učebnic (Simbartl, 2015).

Následně provedeme parametrický test - dvouvýběrový párový t-test na střední hodnotu pro skupinu 6. A a 6 . B vždy pro jejich první a druhý test.

Byl proveden dvouvýběrový párový t-test na střední hodnotu pro skupinu 6 . A první a druhý test na hladině významnosti $\alpha=0,05$. Zjistili jsme hodnotu $p=0,0132457$, protože je hodnota $\mathrm{p}<0,05$ zamítáme tedy $\mathrm{H} 1_{0-\mathrm{PA}}$ pro skupinu 6 . A první a druhý test a přijímáme $\mathrm{H} 1_{\mathrm{A}-\mathrm{PA}}$. Byl prokázán statistický vliv $\mathrm{v}$ hodnocení žákủ prĭi používání interaktivní učebnice ve skupině 6 . A.

Byl proveden dvouvýběrový párový t-test na střední hodnotu pro skupinu 6 . B druhý a první test na hladině významnosti $\alpha=0,05$. Zjistili jsme hodnotu $p=0,0550184$, protože je hodnota $\mathrm{p}>0,05$ príijímáme tedy $\mathrm{H} 1_{0-\mathrm{PB}}$ pro skupinu 6 . B první a druhý test. Nebyl prokázán statistický vliv v hodnocení žákủ při používání interaktivní učebnice ve skupině 6 . B.

\section{Diskuze a závěr}

U obou skupin na základní škole Nýřany tedy kombinace (6. A a 6. B), (6. A a 6. C) byl statisticky prokázán pozitivní vliv na znalosti a myšlenkové operace se znalostmi. Mohli bychom konstatovat, že používání interaktivních učebnic má opravdu vliv na znalosti (a myšlenkové operace se znalostmi), ale nesmíme opomenout ovlivňující faktory.

Ve Starém Plzenci jsme testovali s rotací faktorů, takže si obě skupiny vyzkoušely výuku, kde byly využité interaktivní učebnice. U třídy 6 . A byl prokázán pozitivní vliv 
na použivání interaktivní učebnice. U skupiny 6 . B však pozitivní vliv prokázán nebyl. Měli bychom hledat, proč se tak nestalo. Př́činou mohou být ovlivňující faktory. Některé byly již zmíněny a $\mathrm{v}$ začátku jsou uvedeny jako podmínky, za kterých to bylo prováděno. Jiná byla témata testů a rovněž s tím souvisí i období, kdy byly testy prováděny.

Zaměřili jsme se tedy na druhý test ve Starém Plzenci a zjistili jsme, že střední hodnoty u obou tříd 6. A i 6. B jsou vyšší. U skupiny 6 . B se střední hodnota bodového zisku dokonce snižila. Naznačuje to tak dokonce negativní vliv. Všechny hypotézy však byly jednostranné a uvažovali jsme žádný či pozitivní vliv. Snížení naznačuje i obtížnost testu, která je ale vypočítaná $\mathrm{z}$ výsledků. Rozdíl však není tak značný.

Z celkového zjištění: 3 krát prokázán a 1 krát neprokázán statistický vliv, střední hodnoty, obtížnosti testů a hospitace, odmítáme hlavní hypotézu: „H1 Skupina vyučovaná za pomocí interaktivní učebnice dosáhne lepšich studijnich výsledkù $z$ didaktických testů na znalosti a myšlenkové operace se znalostmi než skupina vyučovaná pouze pomocí papírových učebnic "(Simbartl, 2015).

Tyto výsledky jsme uznali na základě komplexního zhodnocení všech zmíněných částí a především neprokázání statistického vlivu u poslední skupiny. Dle všech těchto zjištění je nejvíce pravděpodobné, že největší vliv mělo samotné téma testu, protože mohlo být pro žáky bližší či snadněji naučitelné. Dále zde může hrát v některých príípadech i datum konání testu, kdy se blíží uzavírání známek a děti mají větší snahu.

Všechna zmíněná tvrzení jsou platná pouze pro náš pedagogický experiment. K úplnému potvrzení nebo vyvrácení využití těchto učebnic, by bylo vhodné ještě dále rozšířit testovaný vzorek na více školách. Abychom odstranili další ovlivňující faktor, museli bychom provést testování na školách ve stejnou dobu a na stejné téma.

$\mathrm{Z}$ našeho pedagogického experimentu jsme tak zatím získali podobné výsledky jako např. (Regueira, 2015), že „se bodové výsledky z testů nezvýšily“. V České republice provádělo testování nakladatelství Fraus. Zde probíhala výuka systémem 1:1 za pomocí netbooků. Bylo zjištěno, že interaktivní učebnice nemají značný vliv (Mazáčová et al., 2012). Pozitivní změnu znalostí oproti tomu zaznamenal pilotní projekt používání aplikace HMH Fuse (Houghton Mifflin Harcourt Publishing Company), kde ze skupiny studentů (vzorek 1072 studentů), která využívala pro výuku zmíněnou aplikaci, byl rozdíl 19 \% v lepším výsledku zkoušky pro uživatele aplikace. Tento rozdíl je velmi významný.

Důležitý poznatek z těchto výzkumů bude zjištění, zda mají skutečně tyto prostředky vliv na znalosti žáků nebo jsou to pouze moderní výukové prostředky pro zpestření výuky a v některých případech usnadnění práce učiteli. Cíleně zaměřené aplikace, které lépe mohou znázornit probíraný jev tak mohou mít výhodu, oproti celé interaktivní učebnici, nebot' je zatím interaktivní pouze v některých cástech.

\section{Literatura}

Červený, P., Dokoupil, J., Kopp, J., Matušková, A., \& Mentlík, P. (2009). Zeměpis 6: pro základní školy a viceletá gymnázia. Plzeň, Fraus.

Houghton Mifflin Harcourt Publishing Company. (n.d.). Results of a yearlong Algebra pilot in Riverside, CA [PDF]. Dostupné z WWW:

$<$ http://www.hmhco.com/ /media/sites/home/educators/education-topics/hmh-

efficacy/hmh_fuse_riverside_whitepaper_2012.pdf?la=en >

Chráska, M. (1999). Didaktické testy: Přrručka pro učitele a studenty učitelství. Brno: Paido. 
Kalhous, Z., \& Obst, O. (2009). Školní didaktika. Praha: Portál.

Mazáčová, N., Hofmannová, M., Chvál, M., Kloboučková, J., \& Vondrová, N. (2012). Projekt VZDĚLÁNÍ21 (Hodnoticí zpráva červen 2012). Dostupné z WWW:

<http://www.vzdelani21.cz/download/v21/84-v21-zaverecnazpravauk-2012.pdf.pdf>

Pearson Plc. (n.d.). Textbooks go digital. [cit. 2016-06-28]. Dostupné z WWW:

<http://thelearningcurve.pearson.com/case-studies/article/textbooks-go-digital/desktop/1>

Regueira, N. R., \& Rodríguez, J. R. (2015). The digital textbook. A look at the current state of the art. Digital Textbooks, What's New? Dostupné z WWW: <http://laeremiddel.dk/wpcontent/uploads/2015/01/759-99z_manuscrito-de-libro-1085-1-10-20141218-2.pdf>

Simbartl, Petr. (2015). Validace interaktivnich učebnic pro základní školy. Plzeň. Disertační práce. ZČU v Plzni.

VBM Service GmbH. (n.d.). [cit. 2016-06-28]. Dostupné z WWW: <http://www.digitaleschulbuecher.de/> 